\title{
Stand Reduction and Foliage Damage Reduce Yield of Dehydrating Onion
}

\author{
George H. Clough \\ Department of Horticulture, Oregon State University, Hermiston Agricultural \\ Research and Extension Center, P.O. Box 105, Hermiston, OR 97838
}

Additional index words. Allium cepa, defoliation, hail injury

\begin{abstract}
Field trials were conducted at Hermiston, Ore., from 1995 through 1998, to determine impact of stand loss and plant damage at different growth stages on yield of onions (Allium cepa) grown for dehydration. Stand reduction $(0 \%, 20 \%, 40 \%, 60 \%, 80 \%)$ and foliage damage $(0 \%, 25 \%, 50 \%, 75 \%, 100 \%)$ treatments were applied at three-, six-, nine-, and twelve-leaf onion growth stages. Although average bulb weight increased as stand was reduced, marketable, cull, and total yields decreased as stand reduction increased (plant population decreased) at all plant growth stages. Bulb weight was not changed by up to $100 \%$ foliage removal at the three-leaf stage. At the six- and twelve-leaf stages, weight was reduced when $\geq 50 \%$ of the foliage was removed. The most severe response occurred at the nine-leaf stage. At the three-leaf stage, yield was not affected by foliage damage. At the six-leaf growth stage, yield was reduced by $75 \%$ or more foliage loss, but at the nine- and twelve-leaf stages, $\geq \mathbf{5 0 \%}$ foliage removal reduced expected yields. As with bulb weight, the impact of foliage removal on yield was most severe at the nine-leaf growth stage.
\end{abstract}

Onion grown for dehydration is a specialty crop, produced primarily in the southwestern U.S., but with 800 ha cultivated in the Columbia basin of the Pacific Northwest. Yield losses due to hail occur frequently in this region. The losses depend upon the level of defoliation and/ or stand reduction and stage of crop growth at the time the damage occurs. Several researchers have described the effects of foliage loss and stand reduction on yield and size distribution for fresh-market and storage onion and actuary tables for stand reduction and foliage damage have been developed (NCIS, 1992). Baker and Wilcox (1961) reported little effect on yield when onion were defoliated either before the three-leaf stage or within 3 weeks of harvest, with the most severe response at the ten-leaf stage of development. They also reported a reduction in yield concurrent with stand reduction at any growth stage, which became more severe as the season progressed. Bartolo et al. (1994) found that defoliation of sweet Spanish onion had the greatest impact on total and market-class yields when it occurred at the onset of bulbing. While total yields were reduced somewhat, the yield of the larger sized bulbs was reduced substantially, while yield of smaller sized onion increased. For the very specialized dehydrating onion, total processable tonnage (bulbs $\geq 3.2 \mathrm{~cm}$ diameter), not yield by size category, is economically important. Other major production differences include higher plant population $(\geq 1,325,000$ plants/ha) and varieties which produce smaller bulbs with high soluble solids.

Field trials were conducted at Hermiston, Ore., from 1995 through 1998 to determine impact of stand loss and plant damage at different growth stages throughout the season on yield of onions grown for dehydration.

Received for publication 14 Feb. 2003. Accepted for publication 26 Sept. 2003. Research funded by National Crop Insurance Services, Overland Park, Kan.

\section{Materials and Methods}

The experimental design was a randomized complete block, with four replications. Stand reduction $(0 \%, 20 \%, 40 \%, 60 \%, 80 \%)$ and foliage damage $(0 \%, 25 \%, 50 \%, 75 \%$, $100 \%$ ) treatments were applied at three-, six-, nine-, and twelve-leaf onion growth stages. Data for the stand reduction and the foliage damage treatments were analyzed as separate experiments.

Plots were established in a commercial dehydrating onion field, planted the second or third week in April with a Monosem precision vacuum seeder under center-pivot irrigation. In 1995, the first treatment combination was applied at the nine-leaf stage of growth. In 1997, the growing season was shortened because the crop had to be replanted (May 6) due to severe wind damage. The soil was an Adkins fine sandy loam (coarse-loamy, mixed mesic Xerollic Camborthid). Normal commercial production practices were followed
(Oregon State Univ. Coop. Ext. Serv., 1997). Each plot was $3 \mathrm{~m}$ long, with four rows per bed of 'Southport' white-globe dehydrating onion (Gilroy Foods, Inc., Gilroy, Calif.). Inrow seed spacing was $3.5 \mathrm{~cm}$, rows were 6.4 $\mathrm{cm}$ apart and beds were on $86-\mathrm{cm}$ centers. The average plant population was determined by counting the number of plants per plot in 16 plots; stands were reduced to treatment levels by random hand-pulling, while maintaining a relatively uniform plant spacing. and bulb diameter was measured on 30 bulbs at each treatment time (Table 1). In each plot, average plant height was determined and foliage was reduced to the various treatment levels (as a percent of average plant height for that plot) with pruning shears.

Plots were harvested in the last 2 weeks in August according to the processors schedule, when $65 \%$ or more of the tops had fallen. Plants were mechanically undercut, roots and tops were trimmed by hand, and bulbs were handsized (marketable $\geq 3.2 \mathrm{~cm}$ diameter, cull $<3.2$ $\mathrm{cm}$ diameter), counted, and weighed.

Due to variability from year to year in total yield, data were converted to percent of maximum (control) yield for regression analysis and development of predictive equations for calculating effect of stand loss or foliage damage on production parameters. Data were evaluated with the SAS GLM and SAS Reg procedures for statistical analysis (SAS Institute, 1988).

\section{Results and Discussion}

Stand reduction. Marketable, cull and total onion yields decreased linearly while average bulb weight increased as stand reduction in-

Table 1. Average dehydrating onion plant development at treatment application at Hermiston, Ore., 1995-98.

\begin{tabular}{lcc}
\hline Stage & $\begin{array}{c}\text { Plant } \\
\text { ht } \\
(\mathrm{cm})\end{array}$ & $\begin{array}{l}\text { Bulb } \\
\text { diam } \\
(\mathrm{cm})\end{array}$ \\
\hline Three-leaf & 15.7 & 0.53 \\
Six-leaf & 30.5 & 1.50 \\
Nine-leaf & 59.9 & 2.26 \\
Twelve-leaf & 63.5 & 3.76 \\
\hline
\end{tabular}

Table 2. Dehydrating onion production as affected by stand reduction and foliage damage at Hermiston, Ore., 1995-98.

\begin{tabular}{|c|c|c|c|c|c|c|c|}
\hline \multirow[b]{2}{*}{ Treatment } & \multicolumn{3}{|c|}{ Marketable ( $\geq 3.2 \mathrm{~cm}$ diam) } & \multicolumn{2}{|c|}{ Cull } & \multicolumn{2}{|c|}{ Total } \\
\hline & $\begin{array}{c}\text { No. } \\
\text { (1000/ha) }\end{array}$ & $\begin{array}{c}\text { Yield } \\
\left(\mathrm{t} \cdot \mathrm{ha}^{-1}\right)\end{array}$ & $\begin{array}{c}\text { Bulb wt } \\
\text { (g) }\end{array}$ & $\begin{array}{c}\text { No. } \\
\text { (1000/ha) }\end{array}$ & $\begin{array}{c}\text { Yield } \\
\left(\mathrm{t} \cdot \mathrm{ha}^{-1}\right)\end{array}$ & $\begin{array}{c}\text { No. } \\
\text { (1000/ha) }\end{array}$ & $\begin{array}{c}\text { Yield } \\
\left(\mathrm{t} \cdot \mathrm{ha}^{-1}\right)\end{array}$ \\
\hline \multicolumn{8}{|c|}{ Stand reduction (\%) } \\
\hline 0 & 726 a & $45.1 \mathrm{a}$ & $62.7 \mathrm{~d}$ & $91.2 \mathrm{a}$ & $1.2 \mathrm{a}$ & $817 \mathrm{a}$ & $46.3 \mathrm{a}$ \\
\hline 20 & $579 \mathrm{~b}$ & $39.3 \mathrm{~b}$ & $65.3 \mathrm{~d}$ & $62.3 \mathrm{~b}$ & $0.9 \mathrm{~b}$ & $641 \mathrm{~b}$ & $40.2 \mathrm{~b}$ \\
\hline 40 & $442 \mathrm{c}$ & $30.9 \mathrm{c}$ & $69.8 \mathrm{c}$ & $37.8 \mathrm{c}$ & $0.5 \mathrm{c}$ & $480 \mathrm{c}$ & $31.4 \mathrm{c}$ \\
\hline 60 & $304 \mathrm{~d}$ & $24.7 \mathrm{~d}$ & $78.9 \mathrm{~b}$ & $22.4 \mathrm{~d}$ & $0.3 \mathrm{~d}$ & $326 \mathrm{~d}$ & $25.0 \mathrm{~d}$ \\
\hline 80 & $172 \mathrm{e}$ & $15.4 \mathrm{e}$ & $91.9 \mathrm{a}$ & $6.9 \mathrm{e}$ & $0.1 \mathrm{e}$ & $179 \mathrm{e}$ & $15.5 \mathrm{e}$ \\
\hline Significance & $\mathrm{L}^{* * * *}$ & $\mathrm{~L}^{* * * * *}$ & $\mathrm{~L}^{* * * * *}$ & $\mathrm{~L}^{* * * *} \mathrm{Q}^{* * *}$ & $\mathrm{~L}^{* * * *} \mathrm{Q}^{* *}$ & $\mathrm{~L}^{* * * * *}$ & $\mathrm{~L}^{* * * * *}$ \\
\hline \multicolumn{8}{|c|}{ Foliage damage (\%) } \\
\hline 0 & $704 \mathrm{ab}$ & $43.5 \mathrm{a}$ & $62.7 \mathrm{a}$ & $91 \mathrm{c}$ & $1.2 \mathrm{c}$ & 795 & $44.7 \mathrm{a}$ \\
\hline 25 & $724 \mathrm{a}$ & $42.6 \mathrm{a}$ & $59.3 \mathrm{~b}$ & $92 \mathrm{c}$ & $1.2 \mathrm{c}$ & 816 & $43.8 \mathrm{a}$ \\
\hline 50 & $684 \mathrm{~b}$ & $35.9 \mathrm{~b}$ & $52.2 \mathrm{c}$ & $106 \mathrm{c}$ & $1.6 \mathrm{c}$ & 790 & $36.5 \mathrm{~b}$ \\
\hline 75 & $635 \mathrm{c}$ & $29.6 \mathrm{c}$ & $46.3 \mathrm{~d}$ & $165 \mathrm{~b}$ & $2.4 \mathrm{~b}$ & 800 & $32.0 \mathrm{c}$ \\
\hline 100 & $512 \mathrm{~d}$ & $22.9 \mathrm{~d}$ & $41.4 \mathrm{e}$ & $248 \mathrm{a}$ & $3.1 \mathrm{a}$ & 760 & $25.9 \mathrm{~d}$ \\
\hline Significance & $\mathrm{L}^{* * * * *}$ & $\mathrm{~L}^{* * * * *}$ & $\mathrm{~L}^{* * * *}$ & $\mathrm{~L}^{* * * * *}$ & $\mathrm{~L}^{* * * *}$ & NS & $\mathrm{L}^{* * * *}$ \\
\hline
\end{tabular}

0.001 , or 0.0001 , respectively. Means followed by different letters are significantly different at $P=0.05$ (Duncan's multiple range test). 


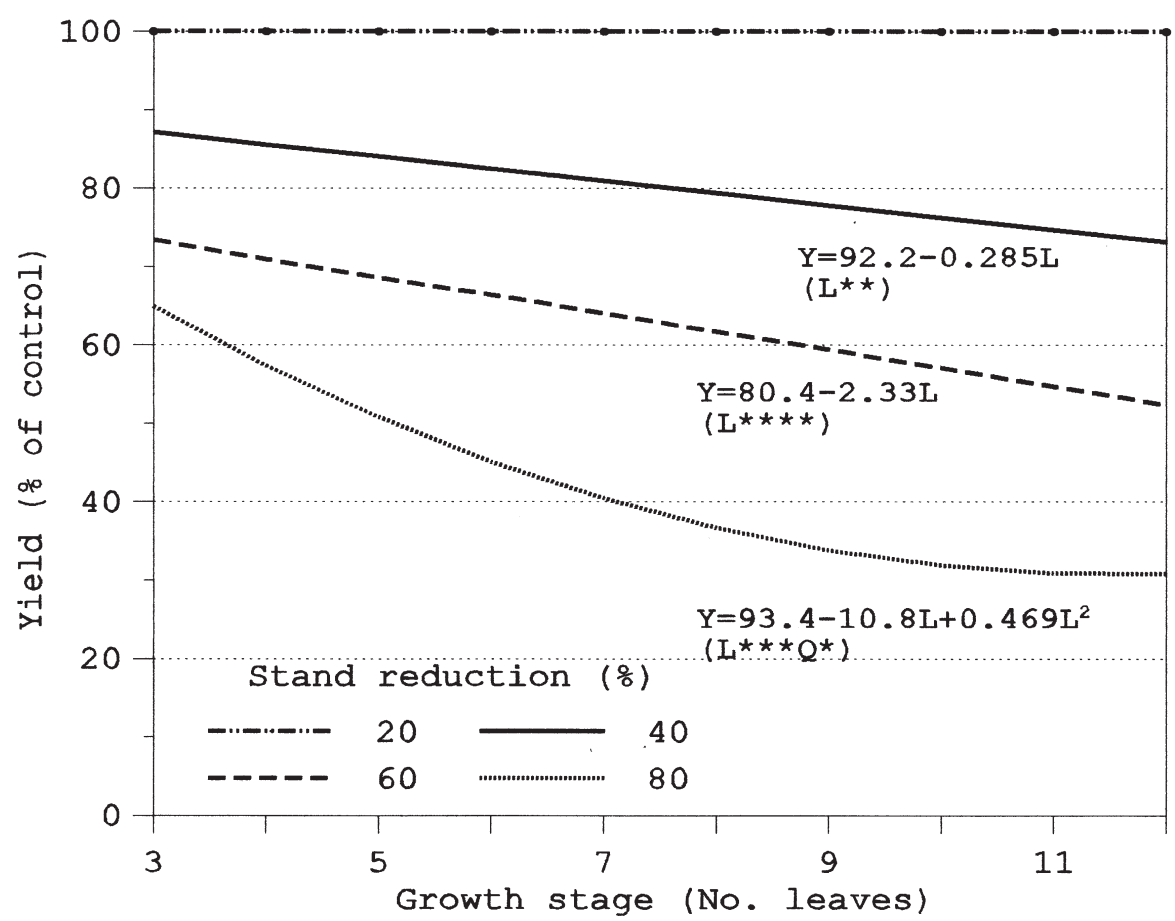

Fig. 1. Regression plots for strand reduction effect at different growth stages on relative yield of dehydrating onion, Hermiston, Ore., 1995-98.

Table 3. Dehydrating onion average bulb weight as affected by interaction of stand reduction and growth stage at Hermiston, Ore., 1995-98.

\begin{tabular}{|c|c|c|c|c|c|c|}
\hline \multirow{3}{*}{$\begin{array}{l}\text { Growth } \\
\text { stage }\end{array}$} & \multicolumn{5}{|c|}{ Bulb wt (g) } & \multirow[b]{3}{*}{ Significance } \\
\hline & \multicolumn{5}{|c|}{ Stand reduction $(\%)$} & \\
\hline & 0 & 20 & 40 & 60 & 80 & \\
\hline \multicolumn{7}{|l|}{ No. leaves } \\
\hline 3 & 62.1 & 70.7 & 74.3 & $95.1 \mathrm{a}$ & $99.9 \mathrm{a}$ & $\mathrm{L}^{* * * *}$ \\
\hline 6 & 64.4 & 68.1 & 76.6 & $92.8 \mathrm{a}$ & $104.0 \mathrm{a}$ & $\mathrm{L}^{* * * * *}$ \\
\hline 9 & 60.5 & 66.4 & 70.4 & $80.4 \mathrm{~b}$ & $94.9 \mathrm{a}$ & $\mathrm{L}^{* * * * *} \mathrm{Q}^{* *}$ \\
\hline 12 & 60.2 & 66.2 & 63.3 & $70.5 \mathrm{c}$ & $76.5 \mathrm{~b}$ & $\mathrm{~L}^{* * * * *}$ \\
\hline Significance & NS & NS & NS & $* * *$ & $* * *$ & \\
\hline
\end{tabular}

${ }_{\mathrm{Ns}, *, * * * *}$ Treatment response nonsignificant or linear $(\mathrm{L})$ or quadratic $(\mathrm{Q})$ and significant at $P=0.01,0.001$, or 0.0001 , respectively. Means followed by different letters are significantly different at $P=0.05$ (Duncan's multiple range test).

Table 4. Dehydrating onion percent marketable yield as affected by interaction of stand reduction and growth stage at Hermiston, Ore., 1995-98.

\begin{tabular}{|c|c|c|c|c|}
\hline \multirow{3}{*}{$\begin{array}{l}\text { Stand } \\
\text { reduction } \\
(\%)\end{array}$} & \multicolumn{4}{|c|}{ Marketable yield (\%) } \\
\hline & \multicolumn{4}{|c|}{ Growth stage (no. leaves) } \\
\hline & 3 & 6 & 9 & 12 \\
\hline 0 & $100.0 \mathrm{a}$ & $100.0 \mathrm{a}$ & $100.0 \mathrm{a}$ & $100.0 \mathrm{a}$ \\
\hline 20 & $89.6 \mathrm{a}$ & $91.8 \mathrm{~b}$ & $92.9 \mathrm{a}$ & $86.3 \mathrm{~b}$ \\
\hline 40 & $89.5 \mathrm{a}$ & $78.5 \mathrm{c}$ & $78.7 \mathrm{~b}$ & $73.7 \mathrm{c}$ \\
\hline 60 & $74.1 \mathrm{~b}$ & $63.5 \mathrm{~d}$ & $62.1 \mathrm{c}$ & $51.3 \mathrm{~d}$ \\
\hline 80 & $66.7 \mathrm{~b}$ & $40.3 \mathrm{e}$ & $37.4 \mathrm{~d}$ & $29.4 \mathrm{e}$ \\
\hline Significance & $\mathrm{L}^{* * * * *}$ & $\mathrm{~L}^{* * * *} \mathrm{Q}^{* *}$ & $\mathrm{~L}^{* * * *} \mathrm{Q}^{* * * *}$ & $\mathrm{~L}^{* * * * *} \mathrm{Q}^{* *}$ \\
\hline
\end{tabular}

${ }_{\mathrm{Ns}, * * * * * * * * * * *}$ Treatment response nonsignificant or linear $(\mathrm{L})$ or quadratic $(\mathrm{Q})$ and significant at $P=0.01,0.001$, or 0.0001 , respectively. Means followed by different letters are significantly different at $P=0.05$ (Duncan's multiple range test).

Table 5. Dehydrating onion average bulb weight as affected by interaction of foliage damage and stage of growth at Hermiston, Ore., 1995-98.

\begin{tabular}{lcccc}
\hline Foliage & \multicolumn{4}{c}{ Bulb wt $(\mathrm{g})$} \\
\cline { 2 - 5 } damage & \multicolumn{4}{c}{ Growth stage $($ no. leaves) } \\
\cline { 2 - 5 }$(\%)$ & 61.3 & 6 & 9 & 12 \\
\hline 0 & 61.3 & $62.4 \mathrm{a}$ & $61.0 \mathrm{a}$ & $65.3 \mathrm{a}$ \\
25 & 60.7 & $51.0 \mathrm{a}$ & $55.3 \mathrm{~b}$ & $60.2 \mathrm{a}$ \\
50 & 59.9 & $46.5 \mathrm{~b}$ & $45.4 \mathrm{c}$ & $49.4 \mathrm{~b}$ \\
75 & 53.6 & $41.4 \mathrm{~d}$ & $34.6 \mathrm{~d}$ & $48.5 \mathrm{~b}$ \\
100 & $\mathrm{NS}$ & $\mathrm{L}^{* * * * *} \mathrm{Q}^{*}$ & $32.9 \mathrm{~d}$ & $40.6 \mathrm{c}$ \\
Significance & $\mathrm{L}^{* * * * *}$ & $\mathrm{~L}^{* * * * *}$ \\
\hline ss,****** Treatment response nonsignificant or linear $(\mathrm{L})$ or quadratic $(\mathrm{Q})$ and significant at $P=0.05$ or 0.0001, respectively. \\
Means followed by different letters are significantly different at $P=0.05$ (Duncan's multiple range test).
\end{tabular}

Means followed by different letters are significantly different at $P=0.05$ (Duncan's multiple range test). creased (plant population decreased) at all plant growth stages (Table 2). There was an interaction between plant growth stage and stand reduction on average onion bulb weight. At all stages of growth, bulb weight increased linearly as plant stand was reduced (Table 3 ). However, with plant stand reduced by either $60 \%$ or $80 \%$, the rate of increase in bulb weight decreased as treatments were applied to progressively later stages of growth. As the season progressed, less time remained for compensatory growth related to reduced interplant competition with the lowered plant stands.

Since there was a slight but significant interaction between growth stage and stand reduction effect on percent of marketable yield, data were sorted by growth stages and data analyses performed (Table 4). Except for the $20 \%$ stand reduction treatment, which did not differ from the control, the response at each growth stage was predominantly linear, with a quadratic component. Regression analyses were used to derive predictive equations. The NOINT option was used for regression analyses since a 0 stand must have a 0 yield; model selection used the maximum $R^{2}$ technique (MAXR). The resulting regression equations indicate that the effect of stand reduction on percent marketable yield increased as the plants matured, and the time remaining for compensatory growth was reduced (Fig. 1). Baker and Wilcox (1961) reported similar results with storage onions; although there were fewer bulbs, and bulb weight increased as stand was reduced, the increased size did not compensate in yield for the reduced stand.

Foliage damage. As foliage damage increased, yield, number, and weight of marketable bulbs decreased, while number and yield of cull bulbs increased (Table 2). Total number of bulbs per hectare was not affected by foliage damage, but total yield decreased linearly with increased damage.

Foliage damage interacted with growth stage to affect the average bulb weight (Table 5). Bulb weight was not changed by up to $100 \%$ foliage removal when treatments were applied at the three-leaf stage of growth. At the six-and twelve-leaf stages, weight was reduced when $\geq 50 \%$ of the foliage was removed. At the nineleaf stage defoliation of $\geq 25 \%$ reduced bulb weight. When treatments were applied at the later twelve-leaf stage, bulb diameter was $50 \%$ greater than at the nine-leaf stage (Table 1), and since the onions were nearing maturity and maximum bulb size, the impact of foliage loss was not as severe. Thornton et al. (1991) and Bartolo et al. (1994) reported similar findings for bulb size distribution in spanish onion; yield of jumbo onions decreased while yield of cull onions increased in response to defoliation. The economic impact on spanish onion may be much more severe than with dehydrating onion. Larger spanish onions (jumbo, colossal) bring a premium price; for dehydrating onion, the price remains constant for all marketable onions $\geq 3.2 \mathrm{~cm}$ diameter.

With yield data converted to percent of expected (control), growth stage and foliage damage interacted in their effects on percent yield (Table 6). The response was similar to 
Table 6. Dehydrating onion percent marketable yield as affected by interaction of foliage damage and growth stage at Hermiston, Ore., 1995-98.

\begin{tabular}{lcccc}
\hline Foliage & \multicolumn{4}{c}{ Marketable yield (\%) } \\
\cline { 2 - 5 } damage & \multicolumn{4}{c}{ Growth stage (no. leaves) } \\
\cline { 2 - 5 }$(\%)$ & 3 & 6 & 9 & 12 \\
\hline 0 & 100.0 & $100.0 \mathrm{a}$ & $100.0 \mathrm{a}$ & $100.0 \mathrm{a}$ \\
25 & 101.7 & $96.7 \mathrm{a}$ & $95.0 \mathrm{a}$ & $100.5 \mathrm{a}$ \\
50 & 101.8 & $92.7 \mathrm{a}$ & $71.2 \mathrm{~b}$ & $74.5 \mathrm{~b}$ \\
75 & 99.1 & $70.8 \mathrm{~b}$ & $47.6 \mathrm{c}$ & $67.6 \mathrm{bc}$ \\
100 & 92.3 & $48.7 \mathrm{~b}$ & $26.4 \mathrm{~d}$ & $54.8 \mathrm{c}$ \\
Significance & $\mathrm{NS}$ & $\mathrm{L}^{* * * *} \mathrm{Q}^{* * * * *}$ & $\mathrm{~L}^{* * * *} \mathrm{Q}^{*}$ & $\mathrm{~L}^{* * * * *}$ \\
\hline
\end{tabular}

Ns,*,*****Treatment response nonsignificant or linear $(\mathrm{L})$ or quadratic $(\mathrm{Q})$ and significant at $P=0.05$ or 0.0001 respectively. Means followed by different letters are significantly different at $P=0.05$ (Duncan's multiple range test).

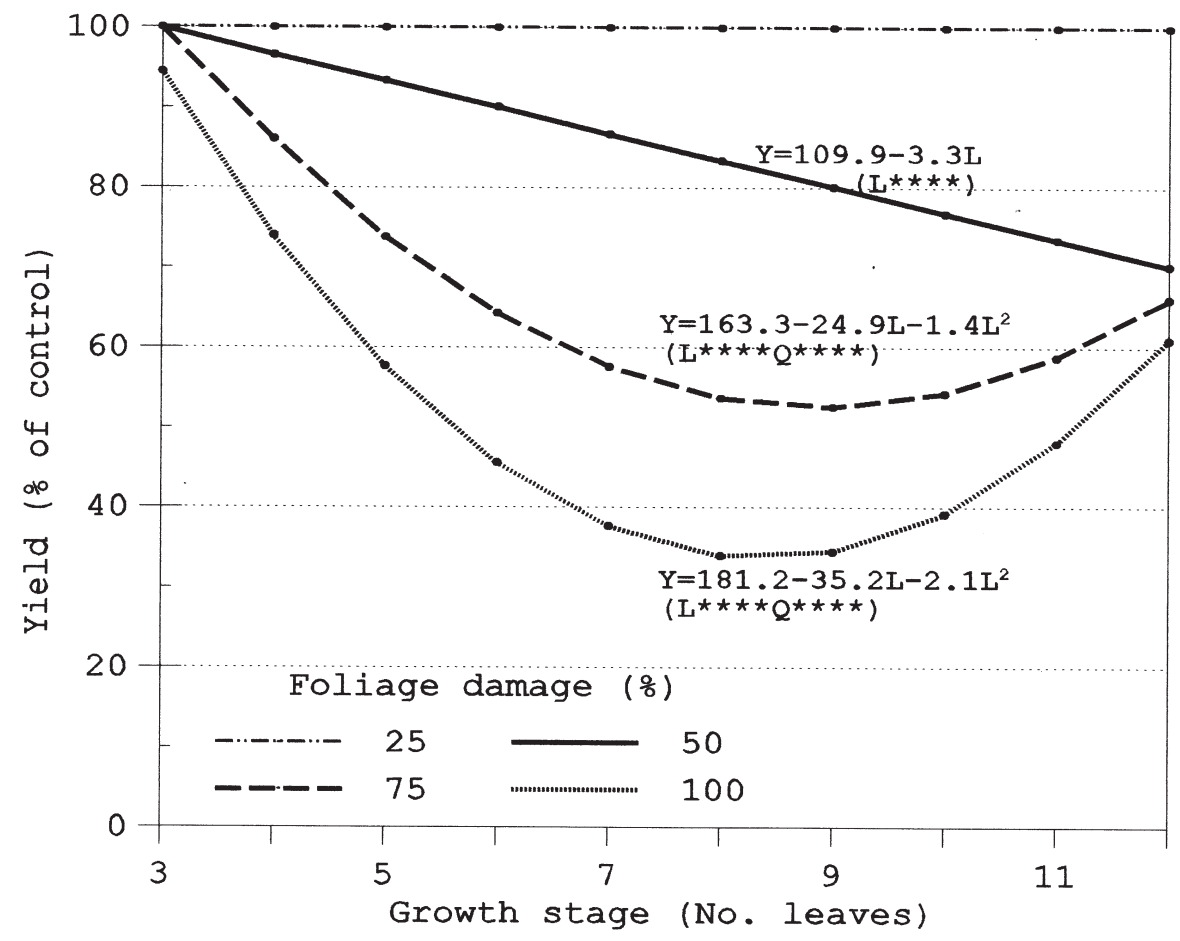

Fig. 2. Regression plots for foliage damage effect at different growth stages on relative yield of dehydrating onion, Hermiston, Ore., 1995-98. average bulb weight results. At the three-leaf stage, yield was not affected by foliage damage. At the six-leaf growth stage, yield was reduced by $\geq 75 \%$ foliage loss, but at the nineand twelve-leaf stages, $\geq 50 \%$ foliage removal reduced expected yields. Baker and Wilcox (1961) also reported that for any given date of defoliation, storage onion yield decreased as defoliation increased; defoliation earlier or later in the season than the ten-leaf stage had less impact on yield.

Regression equations for predicting the impact of different levels of defoliation across the different stages of growth are presented and graphed in Fig. 2. There is no equation for the $25 \%$ foliage removal because that treatment did not affect yield. As with bulb weight, the impact of foliage removal on yield was most severe at the nine-leaf growth stage (Fig. 2). Bartolo et al. (1994) also reported that defoliation at the onset of bulbing ( $56 \mathrm{~d}$ before harvest, equivalent to the nine-leaf stage) had the greatest negative impact on yield of yellow spanish onion; the effect of defoliation at later stages decreased as the crop matured. In this and the cited studies, adequate time remained for vegetative recovery when onions were defoliated earlier than the nine-leaf stage; at the later stages, yield was related to the size of bulbs at the time of defoliation.

\section{Literature Cited}

Baker, R.S. and G.E. Wilcox. 1961. Effect of foliage damage and stand reduction on onion yield. Proc. Amer. Soc. Hort. Sci. 78:401-405.

Bartolo, M.E., H.F. Schwartz, and F.C. Schweissing. 1994. Yield and growth response of onion to simulated storm damage. HortScience 29:1465-1467.

National Crop Insurance Services. 1992. Onion hail loss instructions. NCIS 7430/92.

Oregon State University Cooperative Extension Service. 1997. Onions for dehydration. http:// oregonstate.edu/Dept/NWREC/oniondhy.html

SAS Institute. 1988. SAS/STAT user's guide. Release 6.03 ed. SAS Inst. Inc., Cary, N.C.

Thornton, M.J., C. Shock, J. Catey, and M. Saunders. 1991. Estimating yield loss due to hail damage in onions, p. 48-54. In: Malheur County crop research 1990. Ore. State Univ. Agr. Expt. Sta. Spec. Rpt. 882. 